учителя музики передбачає оцінювання як своїх практичних дій, так і відкритості до етичних цінностей, усебічної відповідальності. Якість музично-естетичного розвитку учнів загальноосвітніх шкіл має особливого значення, оскільки саме на етапі фізичного та психічного розвитку дитини закладається фундамент всебічного розвитку, формується творчий потенціал, розвиваються музичні здібності. Урахування світового педагогічного досвіду необхідне задля здійснення пошуків ефективних способів, залучення учнів загальноосвітніх шкіл до чуттєвого пізнання творів музичного мистецтва, розвитку музичних здібностей, зацікавлення вокально-виконавською діяльністю та творчою діяльністю на уроках музичного мистецтва.

Перспективи подальшого дослідження убачаємо у вивченні досвіду польських педагогів-дослідників щодо розвитку майбутніх учителів музики у вищих навчальних педагогічних закладах освіти.

\title{
Література
}

1. Banach Cz., Edukacja nauczyciela wobec wyzwań transformacji systemowej s reformy edukacji, [w:] A. Siemak-Tylikowska, K. Kwiatkowska, S. M. Kwiatkowski (red.), Edukacja nauczycielska w perspektywie wymagań zmieniającego się świata. - Warszawa, 1998. - 272 s. 2. Kierzkowski M. Analiza wybranych czynników warunkujących rozwój muzychny dziecka / Sztuka. Kultura. Edukacja, red. G. Konkol, Wydawnictwo «Bernardinum», 2010. - 99 s. 3. Kunowski S. Podstawy współczesnej pedagogiki, Warzszawa, 2001. - 312 s. 4. Piątkowska B. Wstęp. Czas na wychowanie. Głównie konteksty i uwarunkowania Barbara Piątkowska (red.). Wałbrzych, 2009. - 309 s. 5. Rutkowiak J. Związek teorii z praktyką pedagogiczną a praca i kshtałcenie nauczycieli. Pytanie, dialog, wychowanie. (w:) (red.) J. Rutkowiak PWN. Warszawa, 1992. - S. 316-336. 6. Sergeant D. C. Experimental investigation of absolute pitch Journal of Research in Music Education. - 1969. - S. 135-143. 7. Schwarz J. Badania nad osobowością nauczyciela. - Wałbrzych : «Nowa Szkola», 1962. - 253 s.

\section{ЗМІСТ, ЗАСОБИ І СТРУКТУРА ДІАГНОСТУВАННЯ РІВНЯ ПІДГОТОВКИ МАЙБУТНІХ ФАРМАЦЕВТІВ У ВИЩИХ НАВЧАЛЬНИХ ЗАКЛАДАХ СХІДНОЄВРОПЕЙСЬКИХ КРАЇН}

Буданова Л. Г. Зміст, засоби і структура діагностування рівня підготовки майбутніх фармацевтів у вищих навчальних закладах східноєвропейських країн.

У статті розкрито та проаналізовано зміст, засоби і структуру діагностування рівня підготовки майбутніх фармацевтів у вищих навчальних закладах східноєвропейських країн за рівнем підготовки, за розподілом навчальних дисциплін за циклами підготовки. Також зазначено знання, практичні навички, необхідні для діагностування підготовки фахівців фармації.

Ключові слова: зміст, засоби, структура, діагностування, рівень підготовки, цикли підготовки, практичні навички.

Буданова Л. Г. Содержание, средства и структура диагностики уровня подготовки будущих фармацевтов в высших учебных заведениях восточноевропейских стран.

В статье раскрыты и проанализированы содержание, средства и структура диагностики уровня подготовки будущих фармацевтов в высших учебных заведениях 
восточноевропейских стран согласно их уровню подготовки, распределению учебных дисциплин по циклам подготовки. Также указаны те знания и практические навыки, которые являються необходимыми для диагностики подготовки специалистов для фармацевтической отрасли.

Ключевые слова: содержание, средства, структура, диагностика, уровень подготовки, циклы подготовки, практические навыки.

Budanova L. G. The content, tools and structure of the diagnostic of future pharmacists' training level in higher educational institutions of Eastern European countries.

The article deals with the content, tools and structure of the diagnostic of future pharmacists' training level in higher educational institutions of Eastern European countries according to their training level, distribution of educational disciplines on training cycles. Knowledge and practical skills that are necessary for the diagnostics of specialist training for pharmaceutical industry have been analyzed. The need for deeper study of foreign higher pharmaceutical education has caused an urgent requirement of time to achieve a higher level of global pharmaceutical sector development. So, it becomes important to analyze the positive experience in reforming foreign higher pharmaceutical education. The experience of Eastern European countries is close to Ukraine. Eastern European and Ukrainian models of future pharmacists' professional training have much in common and distinguishing features caused by historically formed traditions and national features, socio-economic and spiritual development of states, conceptual foundations of educational policy. So, the conducted research has found out that in the educational process the integration of humanitarian and professional component in the training of future specialist for pharmaceutical industry; individualization and differentiation of education; professional orientation in teaching humanitarian, socio-economic and natural sciences haven't been implemented.

Key words: content, tools, structure, diagnosis, level of training, training cycles, practical skills.

Необхідність глибокого вивчення зарубіжної вищої фармацевтичної освіти значною мірою зумовлена нагальною вимогою часу - вийти на вищий світовий рівень розвитку фармацевтичного сектору. Тому важливого значення набуває аналіз позитивного досвіду реформування зарубіжної вищої фармацевтичної освіти.

Близьким для України є досвід східноєвропейських країн, які вже багато років розвиваються в умовах ринкової економіки, налагоджуючи форми співпраці у рамках «загальноєвропейського дому» та інтегруючи багатоукладну економіку до світового ринку. Східноєвропейська та українська моделі професійної підготовки майбутніх провізорів мають багато спільних та відмінних рис, зумовлених історично сформованими традиціями, особливостями національного, соціально-економічного, духовного розвитку держав, концептуальних засад освітньої політики. Цілком закономірно, що досвід східноєвропейських країн щодо професійної підготовки фармацевтичних кадрів становить значний інтерес для вітчизняних педагогів, науковців.

Аналіз останніх досліджень і публікацій останніх років показав, що різні аспекти досліджуваної проблеми висвітлюються в наукових працях, присвячених стратегії розвитку європейської освіти та особливостям підготовки фахівців (Н. Авшенюк, Г. Алексєєвич,
А. Алексюк,
А. Барбарига,
В. Базуріна,
Н. Бідюк,
А. Василюк,
Н. Воскресенська,
Б. Вульфсон, В. Гєрьє， І. Іванюк， К. Корсак， О. Лещинський, А. Лиферов, Г. Лукичов, Г. Марченко, Л. Пуховська, А. Сбруєва, С. Синенько, Н. Федорова) Діагностування рівня 
підготовки засобами педагогічної тестології розглядались у працях вітчизняних (I. Булах, Є. Михайличів, І. Підласий, Л. Романишина, А. Хутірський та ін.) і зарубіжних (Б. Блум, Р. Готтсданкер, К. Інгенкамп, Г. Лиман, Д. Орі, Д. Равен, Ф. Смиз, Е. Стоунс, Є. Торндайк та ін.) педагогів-дослідників. Загальні питання професійної підготовки та змісту професійної освіти розкриті С. Батишевим, В. Галузинським, В. Козаковим, О. Коваленко, В. Лєдньовим, Н. Ничкало, С. Шапоринським, М. Черпінським та ін. Окремі питання підготовки медичних і фармацевтичних кадрів досліджені І. Зупанцем, Є. Мілерян, З. Мнушко, В. Чернихом.

Мета статті полягає в розкритті змісту, засобів і структури діагностування рівня підготовки майбутніх фармацевтів у вищих навчальних закладах східноєвропейських країн.

Формування єдиної «Європи знань», зближення цілей, стандартів, моделей вищої освіти стали адекватною відповіддю вищої школи на зростаючу конкуренцію у світі, особливо з північноамериканським регіоном.

3 початку 90-х років в Україні в системі фармацевтичної освіти, поступально реалізуються міжнародні стандарти, а саме:

- успішно працює інститут магістратури ;

- затверджено державні та галузеві стандарти фармацевтичної освіти;

- в рамках програми якості підготовки кадрів упроваджені інтегровані іспити для діагностики професійних умінь та навичок майбутніх фармацевтів.

Фармацевтична освіта в нашій країні завжди вирізнялася високим новаторським потенціалом. При цьому, зберігаючи великі традиції фармацевтичних шкіл, забезпечуючи високу якість освітніх послуг, демонструючи гнучкість, вона завжди адекватно відповідала усезростаючим вимогам ринку праці.

Особливо наочні в цьому плані докорінні зміни у вищій фармацевтичній освіті, ініційовані Національним фармацевтичним університетом. За останні 20 років наочно збільшився спектр фармацевтичних спеціальностей, зросла кількість фармацевтичних факультетів. Поряд з трьома відомими авторитетними центрами підготовки фармацевтичних кадрів: у Харкові (Національний фармацевтичний університет), у Львові (на фармацевтичному факультеті Львівського національного медичного університету), в Запоріжжі (на фармацевтичному факультеті Запорізького державного медичного університету) відкрито ще 19 факультетів. Отже, в Україні сформувалася потужна система фармацевтичної освіти, наближена до європейської за кількісними показниками.

Проведення дослідження $\epsilon$ актуальним у сучасних умовах. Нині перед вищою фармацевтичною освітою стоїть нелегке завдання переходу до нового мислення, впровадження основних положень європейської освіти, осмислення сутності передбачуваних реформ. Глибокий аналіз особливостей фармацевтичної освіти 5 східноєвропейських країн допоможе простежити тенденції і прийняти зважене і обгрунтоване рішення.

Тридцять років тому в Європі почав напрацьовуватися політичний консенсус щодо нової ролі вищої освіти, особливо у професійній ії компоненті, на європейському ринку праці, який поступово об'єднується в єдиний економічний простір. Формування єдиної «Європи знань», зближення цілей, стандартів, моделей вищої освіти стали адекватною відповіддю вищої школи на зростаючу конкуренцію у світі, особливо 3 північноамериканським регіоном [1; 3]. Для того щоб вступити до Болонської співдружності Україні необхідно провести серйозний порівняльний аналіз вітчизняної системи науки та освіти з європейською (болонською моделлю). За результатами цього аналізу визначити, що необхідно змінити в нашій системі і почати відповідні реформи. Ці реформи вже не зможуть 
бути «косметичними», вони повинні торкнутися корінних основ нашої науки та освіти. Здійснюючи їх, ми повинні відповісти на питання: чому і як слід навчати в сучасному світі гострої конкуренції? Ми не зможемо уникнути реальної інтеграції вітчизняної науки та освіти. Через відмову від освітньо-кваліфікаційного рівня «спеціаліст» виникне необхідність запропонувати еквівалентну систему іншого рівня [2]. Це особливо важливо для підготовки і кваліфікації лікарів та провізорів. Доведеться приймати нелегкі рішення щодо системи наукових ступенів кандидатів і докторів наук та принципів їх присудження. На шляху цих реформ виникає ще багато складних проблем. Але особливість найближчого періоду часу в тому, що уникнути позначених перетворень вже неможливо.

3 початку 90-х років в Україні в системі освіти, зокрема медичної та фармацевтичної, поступально реалізуються міжнародні стандарти, а саме:

- успішно працює інститут магістратури;

- затверджено державні та галузеві стандарти фармацевтичної освіти;

- в рамках програми якості підготовки кадрів впроваджені інтегровані іспити «Крок $1 »$, «Крок - 2», на черзі «Крок - 3» [2].

Слід також зазначити, що медичні і фармацевтичні спеціальності, як і раніше, залишаються найбільш привабливими для іноземців. Сьогодні 327 тисяч іноземцівпредставників 110 держав, більше половини навчаються в медичних та фармацевтичному ВН3. Не викликає сумніву реалізація в Україні одного 3 найважливіших положень представлених у Болонській декларації, Празькому комюніке та інших документах «Навчання через усе життя». Система безперервної фармацевтичної освіти ефективно працює, але нині зазнає серйозної модернізації.

Мабуть, «слабкою ланкою» в системі фармацевтичної освіти сьогодні $€$ низька активність академічних обмінів студентами та представниками з європейськими ВНЗ, однак і в цьому напрямку окреслені серйозні зрушення.

Другим важливим кроком має стати прийняття урядом усвідомленого рішення, яке грунтувалося б на потребах проведення згаданих реформ і яке було б покладено в основу рішучої зовнішньої політики держави, спрямованої на інтеграцію вітчизняної системи науки та освіти до Європейського простору.

Проаналізовано зміст, засоби і структуру діагностування рівня підготовки майбутніх фармацевтів у таких вищих навчальних закладах східноєвропейських країн: медичний університет, фармацевтичний факультет, Софія, Болгарія; медичний університет, фармацевтичний факультет, Гданськ, Польща; медичний університет, школа фармації, Лодзь, Польща; Варшавська медична академія, фармацевтичний факультет, Варшава, Польща; Ягиллонський університет, факультет фармації та медичної аналітики, Польща; Вроцлавський медичний університет, фармацевтичний факультет, Польща; медичний університет Крайови, фармацевтичний факультет, Румунія; університет медицини та фармації «Карол Давила», фармацевтичний факультет, Румунія; університет Камениус, фармацевтичний факультет, Братислава, Словаччина; Медичний університет Альберт Сент Георги, фармацевтичний факультет, Сегед, Угорщина; медичний универсітет Земмельвайса, фармацевтичний факультет, Угорщина; Печський медичний університет, фармацевтичний факультет, Угорщина: університет Чарльза, Градец-Кралове, фармацевтичний факультет, Чехія [4, с. 23-25; 5; 7]. 
У таблиці № 1 наведено розподіл дисциплін за циклами підготовки.

Таблиця 1.

Розподіл дисциплін у \% за циклами підготовки

\begin{tabular}{|l|c|c|c|c|c|c|c|}
\hline \multicolumn{1}{|c|}{ Країна } & $\begin{array}{c}\text { Хімічні } \\
\text { дисципліни }\end{array}$ & $\begin{array}{c}\text { Фізико- } \\
\text { математичні } \\
\text { дисципліни }\end{array}$ & $\begin{array}{c}\text { Біологіч } \\
\text { ні дисци } \\
\text { пліни }\end{array}$ & $\begin{array}{c}\text { Фармацев } \\
\text { дичні } \\
\text { дициліни }\end{array}$ & $\begin{array}{c}\text { Медичні } \\
\text { дисциплі } \\
\text { ни }\end{array}$ & $\begin{array}{c}\text { Суспільні } \\
\text { науки }\end{array}$ & $\begin{array}{c}\text { дисальні } \\
\text { ліни, } \\
\text { практика }\end{array}$ \\
\hline Болгарія & 31.0 & 7.0 & 11.0 & 13.0 & 24.0 & 7.00 & 7.00 \\
\hline Чехія & 17.0 & 5.0 & 8.0 & 22.0 & 19.0 & 13.00 & 16.00 \\
\hline Угорщина & 27.2 & 5.2 & 5.2 & 16.0 & 28.5 & 3.88 & 14.22 \\
\hline Польща & 21.3 & 4.1 & 8.0 & 15.9 & 38.2 & 6.20 & 6.20 \\
\hline Румунія & 26.1 & 8.7 & 15.8 & 14.1 & 24.9 & 3.70 & 6.60 \\
\hline Словаччина & 28.8 & 8.8 & 10.9 & 14.4 & 27.6 & 3.40 & 6.00 \\
\hline
\end{tabular}

Проаналізовано та представлено у таблиці № 2 терміни та освітньої-кваліфікаційні рівні підготовки.

Таблиця 2.

Терміни підготовки магістрів фармації

\begin{tabular}{|c|c|c|c|c|}
\hline № & Країна & Освітній рівень & Терміни підготовки & Термін практики \\
\hline 1. & Болгарія & Магістр фармації & $5 \mathrm{p}$ & Практика - 10 місяців \\
\hline 2. & Угорщина & Магістр фармаці & 5 p. & $\begin{array}{l}\text { Практика в аптеці - } 6 \\
\text { місяців }\end{array}$ \\
\hline 3. & Польща & Магістр фармації & $5 \mathrm{p}$. & Практика - 12 місяців \\
\hline 4. & Румунія & Магістр фармації & $5 \mathrm{p}$. & Практика - 6 місяців \\
\hline 5. & Словаччина & Магістр фармаці & $5 \mathrm{p}$. & Практика - 6 місяців \\
\hline 6. & Чехія & Магістр фармації & $5 \mathrm{p}$. & Практика -6 місяців \\
\hline
\end{tabular}

Також проаналізовано працевлаштування фармацевтів та наведено у таблиці 3.

Таблиця 3.

Занятість фармацевтів

\begin{tabular}{|c|l|c|c|c|c|}
\hline \multirow{2}{*}{ № } & \multirow{2}{*}{ Країна } & Населення & Громадський & Госпітальний & Промисловий \\
\cline { 3 - 6 } & & $\begin{array}{c}\text { (млн.) } \\
\text { фармацевт }\end{array}$ & $\begin{array}{c}\text { фармацевт } \\
\text { фармацевт }\end{array}$ \\
\hline 1. & Болгарія & 7.6 & 6,000 & 114 & 1000 \\
\hline 2. & Чехія & 10.5 & 6,000 & 220 & 15 \\
\hline 3. & Угорщина & 10 & 4,900 & 350 & 1200 \\
\hline 4. & Польща & 38.1 & 21,534 & 1,100 & NA \\
\hline 5. & Румунія & 21.5 & 13,500 & 692 & 100 \\
\hline 6. & Словаччина & 5.4 & 2,900 & 159 & 200 \\
\hline
\end{tabular}

Проаналізувавши зміст, засоби та структуру діагностування рівня підготовки майбутніх фармацевтів у Болгарії, Чехії, Польщі, Румунії, Угорщині та Словаччині, зазначимо знання, практичні навички, необхідні для діагностування підготовки фахівців фармації у вищезазначених країнах залежно від виду діяльності: Управління (Належна практика закупівель, Уміння вирішувати проблеми, Фармакоекономіка, Облік запасів, інвентаризація; Управління фінансами, Юридична компетентність, Процедура проведення тендера); Фармацевтична допомога (Структура медико-санітарної допомоги, Терапевтичний 
моніторинг Л3, Патофізіологія, Фармакотерапія, Фармакокінетика, Навички внутрішньої та міжпрофесійної / особистої взаємодії, Компетентність у клінічній галузі, Ятрогенні захворювання); Інформація, освіта і спілкування (Збереження, пошук (в електронних базах даних) і використання інформації, Навички спілкування, Знання методів проведення наукових досліджень і оцінки, Навички в соціально-поведінковій сфері); Забезпечення якості (Продукція, послуги, знання процесів, Аналітичні/технічні навички, Навички у сфері контролю якості, Уміння проводити оцінку, Реєстраційний облік); Наукові дослідження у сфері системи охорони здоров'я (Епідеміологія-біостатистика, Громадська охорона здоров’я, Дослідження системи охорони здоров’я, Клінічні дослідження, Оцінка літератури); Фармацевтичне виробництво (Фармацевтична технологія, Прилади, Новаторство, Біофармація і фармацевтична мікробіологія); Регламентування і етика (Закони і нормативні акти для робітників охорони здоров'я, Розв’язання конфліктів, Схеми сертифікації/гармонізації, Медикаменти та нормативний акт (для людини/тварини); Маркетинг (Етичні принципи бізнесу, Навички спілкування, Навички міжособистісних відносин, Навколишнє середовище / робоче місце та фінансові навички) [1].

Проведений аналіз змісту, засобів та діагностування рівня підготовки майбутніх фахівців фармацевтичної галузі засвідчив, що в навчально-виховному процесі не були втілені: інтеграція гуманітарного та фахового складника у професійній підготовці майбутнього фахівця фармацевтичної галузі; індивідуалізація й диференціація навчання; професійна спрямованість у викладанні гуманітарних, соціально-економічних та природничо-наукових дисциплін. Зміст навчальної й виробничої практик спрямований на формування спеціалізовано професійних умінь та навичок i не передбачає формування комунікативних, психологічних компетентностей, професійно важливих якостей майбутніх фахівців фармації.

\section{Література}

1. Згуровський М. 3. Болонський процес - структурна реформа вищої освіти на європейському просторі [Електронний ресурс] / M. З. Згуровський. - Режим доступу : http://kpi.ua/bologna. 2. Наказ МОЗ України від 13.09.2010 р. № 769 «Про затвердження концепції розвитку фармацевтичного сектору галузі охорони здоров’я України на 2011-2020 роки» [Електронний ресурс]. - Режим доступу : http://www.apteka.ua/article/57908 3. Council Directive 85/432/EEC of 16 September 1985 concerning the coordination of provisions laid down by Law, Regulation or Administrative Action in respect of certain activities in the field of pharmacy.Access mode: [Electronic resource]. - Access mode: http://www.aic.lv/ace/ace_disk/Recognition/ dir_prof/SECTORAL/ 85_432 pharm.pdf. 4. Developing pharmacy practice. A focus on patient care. Handbook. - Access mode: [Electronic resource]. - 2006 edition / K. Wiedenmayer, R. S. Summers, C. A. Mackie [etc.]. - WHO with IPF, 2006. - 87 p. fip/publications/ Developing Pharmacy Practice/ DevelopingPharmacyPracticeEN.pdf. 5. FIP statement of policy on good pharmacy education practice [Electronic resource]. - Approved by FIP Council in Vienna in September 2000.- Access mode: http://www.fip.org/www/uploads/ database_file.php?id =188. 6. Офіційний сайт МОНУ. - Режим доступу: http://mon.gov.ua/ ua/activity/ education/58/. [Електронний ресурс]. 7. The role of the pharmacist in the health care system. Preparing the future pharmacist: curricular development [Electronic resource] / Report of the third WHO consultative group on the role of the pharmacist, Vancouver, Canada, 27-29 August 1997. Access mode : http://www.opas.org.br/ medicamentos/site/UploadArq/ who-pharm-97-599.pdf. 